\title{
EM ÁLBUM, OS POVOS DO PURUS REVISITADOS
}

JANE FELIPE BELTRÃO ${ }^{1}$

$U F P A$

\section{RESENHA}

SANTOS, Gilton Mendes dos (Org.). Álbum Purus. Manaus: EDUA, 2011. $344 \mathrm{p}$.

O Álbum "retrata", em sépia e em preto e branco, como os documentos de família guardados pelas avós, os quais se folheiam, página por página, com cuidado e tentando "preservar", na retina, cada detalhe do Rio Purus, que conquista, desde o século XVI, destaque entre viajantes e naturalistas que palmilharam a região amazônica. As páginas do documento apontam o cenário de muitos dramas produzidos pelas frentes de expansão que iniciam a caça às drogas do sertão e tornam-se robustas com a invasão ocorrida nos tempos da borracha.

Viajantes e naturalistas se foram de volta às origens. Mas, ainda hoje, o Purus não recebeu alforria dos conflitos que a sanha dos "pioneiros da marcha pela Amazônia", conduzidos por interesses variados, impõe aos povos indígenas e às diversas populações existentes ao longo das margens e/ou embrenhados na floresta tropical, ainda exuberante, em alguns trechos da maior bacia hidrográfica do mundo. Bacia que tem como cerne o portentoso Solimões ou Amazonas, que se faz árvore frondosa e esgalha a fronde, à direita e à esquerda,

\footnotetext{
${ }^{1}$ Antropóloga e historiadora, docente junto à Universidade Federal do Pará (UFPA). Pesquisadora do CNPq. E-mail: jane.beltrao@pq.cnpq.br.
} 
para dar suporte aos povos que, milenarmente, comandam a vida na região, apesar de parecer que os rios nos oferecem "régua e compasso".

Entre os galhos fotografados em close, destaca-se o rincão do Purus, que Gilton Mendes dos Santos, docente do Programa de PósGraduação em Antropologia Social da Universidade Federal do Amazonas (UFAM), organiza em coletânea denominada Álbum Purus.

Os trabalhos tratam de viagens, viajantes e a empresa extrativa, sem descuidar de territorialidades, recursos naturais e conflitos que se espalham pela região, produzindo respostas e resistências das gentes que habitam o Purus, bem trabalhadas em etnologia e etnografias sobre os povos indígenas que, em caleidoscópio, apresenta a dilaceração produzida pelo "cercamento" dos nativos, rio acima e rio abaixo, indicando o cinismo do desenvolvimento que se pensa, arrogantemente, como sustentável, como denuncia Márcio Souza no prefácio que discute quando a história acontece nos rios.

O trabalho possui uma particularidade que o torna ímpar; foi escrito por acadêmicos experientes, formados em diversos campos do conhecimento, mas traz os iniciantes, jovens que escrevem de forma suave e a pedir desculpas por invadir a seara dos doutores nas sagas do Purus. Entretanto, para quem inicia a jornada, Angélica Vieira, Ingrid de Souza, Jucélya da Silva e Liliane de Souza, bolsistas de IC (Iniciação Científica) do CNPq, mostram quão importante é manter estudantes em formação no ambiente de trabalho de pesquisadores experimentados, como o grupo do Núcleo de Estudos da Amazônia Indígena (NEAI) da UFAM. O resultado deixa marcas no "fazer História" dos povos indígenas do ponto de vista do antropólogo na Amazônia, pois as jovens pesquisadoras trazem a público novas versões sobre 0 "desenvolvimento" dos postos indígenas entre os povos Jamamadi, Kulina e Paumari, apresentando a investida em produzir "um cerco de paz". As autoras, inclusive, recortam da documentação consultada imagens que integram os relatórios do antigo Serviço de Proteção aos Índios (SPI), as quais, de outra forma, permaneceriam relegadas ao esquecimento entre os documentos sob a guarda do Museu do Amazonas. As imagens foram cuidadosamente inseridas no texto, auxiliam a compreensão das atividades mantidas nos postos indígenas e 
deixa, ao estudioso, o gosto de "quero ver mais", exigindo a continuidade da empresa acadêmica.

Diz Gilton dos Santos, na introdução, que os povos nativos ocultos e silenciados pela pena de Euclides da Cunha, vem à cena, nos brindando com modelos de vida e modos de conceber a Amazônia - são indispensáveis ao movimento político da região nos dias de hoje. A afirmação ganha fôlego ao longo dos textos, especialmente quando discutem a dinâmica do mosaico histórico do vale do Purus articulada: pela presença dos povos indígenas; pelo impacto da empresa "caucheira"; pela malha viária de "chão preto", que rasga os territórios tradicionais; pelas ondas de migrantes do passado e do presente; pelas hidrelétricas, que escorraçam os moradores dos rios. São temas tratados pertinentemente pelos textos de Thereza Menezes, Marcelo Franco e Miguel Aparicio, que, para além da realidade apresentada e problematizada, nos obrigam a pensar em outros rios "dirigentes", como o Xingu, o Tocantins e o Tapajós, locais onde o filme "rodado" no Purus "se reproduz". É Aparicio que chama atenção para o processo de mudança, ainda oculto, que caracteriza o novo cenário do Purus indígena. Em busca da perspectiva indígena, o autor informa que a garantia da terra não é suficiente, pois o território requer gestão de recursos naturais disponíveis na floresta.

Diz Aparicio que: [a] territorialidade contemporânea com uma dinâmica de nova economia florestal, e o histórico fluxo dos circuitos de intercâmbio e troca ressurge com o comparecimento das cidades como territórios indígenas que todos teimam em não reconhecer. É impossível negar o "chama" (vocábulo regional que indica a magia de algo) exercida pelas cidades. Na condição de cidadãos, os indígenas demandam benefícios do Estado, como: (1) aposentadoria e transferência de renda; e, por outro lado, (2) nas aldeias há indígenas profissionais remunerados (professores, agentes de saúde e saneamento, entre outros). E embora os povos tradicionais indígenas e não indígenas "dominem" as florestas existentes, muitas vezes os interesses nativos nos circuitos comerciais terminam ferindo a legislação ambiental, pois entre as atividades encontram-se caça, pesca e extrativismo, e os "supervisores" da floresta não compreendem os usos nativos da floresta. 
A disputa se acirra pela "injeção" de moeda no comércio local e "indianiza" algumas cidades da calha do Purus.

Os trabalhos realizados no Rio Purus aprofundam o diálogo acadêmico. A bibliografia produzida sobre o Purus pelos autores da coletânea é um das possíveis maneiras de revisitar o campo e produzir fino entrelaçamento de interpretações permitindo repensar "sem reservas" a Amazônia.

Clayton Rodrigues, Marcelo Florido, Stela Abreu e Fabiana Maizza refletem sobre os conflitos atuais, mas não abandonam os temas clássicos, como organização social e parentesco, retomando, assim, formas do pensar antropológico, situando o leitor na tradição que aos poucos e "sem cerimônia" vem se modificando, mas ainda sustenta as relações sociais vigentes.

Os Suruhaha recebem "tratamento" acadêmico via o trabalho desenvolvido por Miguel Aparicio, dando conta da cosmovisão do povo, permitindo ao leitor compreender o terror implantado pelos seringueiros, que se traduz em temor que permanece vivo na memória daqueles que foram dizimados e vitimados pela voracidade do ciclo da borracha.

As conexões necessárias entre o presente e o passado recente garantem ao leitor a compreensão da diversidade no Purus e a complexidade das relações sociais estabelecidas, tornando o ato de ler uma agradável reflexão.

O que se diz no Álbum faz temer o futuro do Purus, mas, se visto como alerta, pode orientar políticas públicas e militância "consequente" por uma Amazônia sustentável, inclusiva e plural. 